\title{
Using the significant dust deposition event on the glaciers of Mt. Elbrus, Caucasus Mountains, Russia on 5 May 2009 to develop a method for dating and "provenancing" of desert dust events recorded in snow pack
}

\author{
M. Shahgedanova ${ }^{1}$, S. Kutuzov ${ }^{1,2}$, K. H. White ${ }^{1}$, and G. Nosenko ${ }^{2}$ \\ ${ }^{1}$ Department of Geography and Environmental Science and Walker Institute for Climate System Research, \\ The University of Reading, Reading, UK \\ ${ }^{2}$ Laboratory of Glaciology, Institute of Geography, Russian Academy of Sciences, Moscow, Russia
}

Correspondence to: M. Shahgedanova (m.shahgedanova@reading.ac.uk)

Received: 14 June 2012 - Published in Atmos. Chem. Phys. Discuss.: 18 September 2012

Revised: 30 December 2012 - Accepted: 4 January 2013 - Published: 18 February 2013

\begin{abstract}
A significant desert dust deposition event occurred on Mt. Elbrus, Caucasus Mountains, Russia on 5 May 2009, where the deposited dust later appeared as a brown layer in the snow pack. An examination of dust transportation history and analysis of chemical and physical properties of the deposited dust were used to develop a new approach for high-resolution "provenancing" of dust deposition events recorded in snow pack using multiple independent techniques. A combination of SEVIRI red-green-blue composite imagery, MODIS atmospheric optical depth fields derived using the Deep Blue algorithm, air mass trajectories derived with HYSPLIT model and analysis of meteorological data enabled identification of dust source regions with high temporal (hours) and spatial (ca. $100 \mathrm{~km}$ ) resolution. Dust, deposited on 5 May 2009, originated in the foothills of the Djebel Akhdar in eastern Libya where dust sources were activated by the intrusion of cold air from the Mediterranean Sea and Saharan low pressure system and transported to the Caucasus along the eastern Mediterranean coast, Syria and Turkey. Particles with an average diameter below $8 \mu \mathrm{m}$ accounted for $90 \%$ of the measured particles in the sample with a mean of $3.58 \mu \mathrm{m}$, median $2.48 \mu \mathrm{m}$. The chemical signature of this long-travelled dust was significantly different from the locally-produced dust and close to that of soils collected in a palaeolake in the source region, in concentrations of hematite. Potential addition of dust from a secondary source in northern Mesopotamia introduced uncertainty in the "provenancing" of dust from this event. Nevertheless,
\end{abstract}

the approach adopted here enables other dust horizons in the snowpack to be linked to specific dust transport events recorded in remote sensing and meteorological data archives.

\section{Introduction}

Impacts of dust deposition on glaciated environments recently came to prominence in the light of accelerated retreat of glaciers worldwide. Dust deposited on glaciers originates from different sources including long-travelled desert dust (LTD), locally-produced mineral dust (LPD) and products of decay of biogenic material. Mineral dust changes reflectance of glacier surfaces, affecting energy balance and melt rates of glaciers and seasonal snow and subsequently runoff $(\mathrm{Fu}-$ jita, 2007). Analysis of sensitivity of Vadret da Morteratsch Glacier's (Swiss Alps) melt to declining surface reflectance has shown that a $10 \%$ decrease in glacier reflectance has the same impact as $1.7 \mathrm{~K}$ warming (Oerlemans et al., 2009). LTD affects geochemical cycles of high-altitude environments through the supply of iron and other nutrients to the aquatic systems nourished by snow and glacier runoff (Marx et al., 2005). It serves as a vector for the transportation of anthropogenic pollution leading to increasing concentrations of metals in snow and ice (Hong et al., 1996; Marx et al., 2005). Globally, about $30 \%$ of the total land area is a potential source of mineral dust for the atmosphere (Sokolik and Toon, 1996). This area is predicted to increase in response to 
human activities (Sheehy, 1992), leading to a growth in emissions of mineral dust and their stronger impacts in distant regions. Desert dust is emitted from preferential source regions and its chemical composition and seasonality of mobilisation and transportation vary between regions (Schepanski et al., 2009). It is important to know dust provenance in order to understand its potential geochemical impacts and effects on glacier melt, due to the variation in reflectance properties and timing of deposition in relation to the onset of melt season.

A number of studies focused on provenance and chemistry of LTD deposited in the European Alps (Schwikowski et al., 1995; Grousset et al., 2003; Sodemann et al., 2006), New Zealand (Marx et al., 2005; McGowan et al., 2005), Central Asia (Takeuchi and Li, 2008; Dong et al., 2009), the Himalayas and Tibetan Plateau (Kang et al., 2010; Prasad et al., 2009), and mountains of Japan (Osada et al., 2004). One of the glacierized regions which is affected by LTD deposition but has so far evaded scrutiny is the Caucasus Mountains, located between the Black and the Caspian Seas. The Caucasus accommodates about 2000 glaciers covering approximately $1600 \mathrm{~km}^{2}$ whose retreat intensified since the 1980 s with a combined glaciated area loss of $10 \%$ between 1985 and 2000 (Stokes et al., 2006). Although there has been research on regional snow chemistry (e.g. Rototaeva et al., 1998, 1999), characteristics of mineral dust, its provenance and effects on the Caucasus glaciers have not been studied.

Due to its elevation (over $5000 \mathrm{~m}$ a.s.l.), proximity to the deserts of the Middle East, Kazakhstan and Central Asia and location on the track of Saharan depressions, $25 \%$ of which migrate to the region (Hannachi et al., 2011), the Caucasus is a perfect LTD trap. High elevations ensure solid precipitation throughout the year and absence of significant seasonal melt above approximately $4600 \mathrm{~m}$ a.s.l. Free tropospheric conditions prevail over $4000 \mathrm{~m}$ in winter and spring and, consequently, these elevations are not reached by local polluted air masses and aerosol deposition is associated with longrange transport. The Caucasus glaciers can serve as archives of LTD deposition events clearly identifiable as brown layers in snow and ice and these can be used to improve the current knowledge of pathways of desert dust in the atmosphere. The source regions of LTD can be identified through detailed geochemical analyses (e.g. Marx et al., 2005). However, additional application of multiple independent techniques including air trajectory models and examination of local meteorological and synoptic conditions leading to dust mobilisation, transportation and deposition, provides more reliable and detailed "provenancing", especially if multiple source regions are present (Grousset et al., 2003; Osada et al., 2004; Sodeman et al., 2006). One limitation of these methods is uncertainty associated with calculation of back trajectories, reaching 15-30\% of the travel distance (Draxler and Rolph, 2012). Another limitation is the requirement for precise timing of dust deposition events, which may not be registered by meteorological stations that are mostly located in valleys. Examination of snow and ice profiles for the occurrence of thin crusts of ice, which form in late spring-early summer in response to increasing insolation and serve as stratigraphic markers, and application of isotopic analysis, allows one to establish in which month or season a dust deposition event occurred, but does not enable dating to a precision of specific days.

A very significant dust deposition event occurred in the central Greater Caucasus on 5 May 2009 between 05:00 and 06:00 UTC (8-9 h local time). Following a red-brown snowfall, a layer of dust formed on the snow pack of Mt. Elbrus (5642 m a.s.l.; location shown in Fig. 2) and the surrounding mountains. This dust was subsequently covered by snow, but this melted out at lower elevations in mid-summer and was clearly visible on an ASTER satellite image acquired on 4 August 2009 (not shown).

This paper has two objectives. The first objective is to examine pathways of the Saharan dust north-east of southern and central Europe and the eastern Mediterranean region and, for the first time examine physical and chemical properties of desert dust deposited on the Caucasus glaciers. The second objective is to test a suite of "provenancing" techniques on the results of this event, which could be used to examine and date other dust deposition events recorded in the snow and ice, in order to construct dust deposition climatologies (including high-resolution "provenancing") in the Caucasus Mountains using shallow ice cores in the future. The proposed combination of techniques includes a range of remote sensing products designed specifically for tracking dust mobilisation and transportation events, as well as meteorological analysis and air trajectory modelling.

\section{Data and methods}

\subsection{Dust sample collection and analyses}

The LTD was sampled from the surface of the Garabashi Glacier on the south-eastern slope of Mt. Elbrus $\left(43^{\circ} 18^{\prime} 16.8^{\prime \prime} \mathrm{N}, \quad 42^{\circ} 27^{\prime} 48.4^{\prime \prime} \mathrm{E}\right)$ at $3856 \mathrm{~m}$ a.s.l. The dust sample was collected with a plastic spatula from a snow-covered area of $1 \mathrm{~m}^{2}$ following the deposition event, stored in a clean plastic bottle and filtered using $0.2 \mu \mathrm{m}$ filters for particle size distribution and elemental composition analyses. Two sets of control samples (Table 1) were used for comparison of elemental composition: (i) local samples (LS) from Mt. Elbrus and (ii) Saharan soils (SS) from the El Mechili region in Djebel Akhdar, one of the known persistent sources of dust in eastern Libya, and which was identified as a potential source region of dust deposited on Mt. Elbrus on 5 May 2009.

Particle size distributions were obtained using environmental scanning electron microscope (SEM) FEI Quanta FEG600. Sections of filters containing dust particles were cut out, and four and five SEM images were acquired at 2000 and 5000 magnifications, respectively. Scandium software was 
Table 1. Details of the control samples from Mt. Elbrus (LS) and El Mechili region in north-eastern Libya (SS).

\begin{tabular}{lll}
\hline Sample & Geographical coordinates & Description of sample and collection point \\
\hline LS1 & $43.264969^{\circ} \mathrm{N}, 42.472613^{\circ} \mathrm{E}$ & Fine sediment from local stream; 2380 m a.s.l. \\
LS2 & $43.266585^{\circ} \mathrm{N}, 42.488096^{\circ} \mathrm{E}$ & Fine sediment from local stream; 2390 m a.s.l. \\
LS3 & $43.303765^{\circ} \mathrm{N}, 42.460900^{\circ} \mathrm{E}$ & LPD with traces of LTD from glacier surface near exposed rocks; $3860 \mathrm{~m}$ a.s.l. \\
SS1 & $32.50101^{\circ} \mathrm{N}, 22.21978^{\circ} \mathrm{E}$ & A small tributary channel \\
SS2 & $32.0144^{\circ} \mathrm{N}, 22.27333^{\circ} \mathrm{E}$ & Palaeolake surface \\
SS3 & $32.04504^{\circ} \mathrm{N}, 22.30025^{\circ} \mathrm{E}$ & Ploughed area on edge of active fan wash \\
\hline
\end{tabular}

used for analysis: 2100 particles, all which could be distinguished on the images, were manually digitised and their geometric characteristics were automatically measured by the software. Manual digitisation was used to avoid the problem of particle overlapping. To characterise particle size, average particle diameter defined as diameter of a circle with equivalent area (Reid et al., 2003a) was used. The cut-off point for particle size is defined here as $0.2 \mu \mathrm{m}$.

Electron microscopy is currently one of the most widely used methods of particle size analysis in application to both airborne aerosol (e.g. Reid et al., 2003 a, b; Abed et al., 2009; Kandler et al., 2011) and mineral dust deposited on ice and snow (e.g. Li et al., 2011). An advantage of this method is in its ability to identify unusual particle shapes, deposition patterns and presence of such material as diatoms and pollen which may provide further insight into the origin of dust. One of the limitations is undersampling of ultrafine particles due to both the filter pore size and uncertainties in calculation of their parameters. However, a comparison of different methods of particle size characterization by Reid et al. (2003b) has shown that bias towards coarser particles is lower when using SEM in comparison with optical particle counters. Similarly Royer et al. (1983) used both SEM and Coulter counter to derive particle size distributions from samples of dust contained in an Antarctic ice core and found that while both methods generated distributions that are similar in shape, SEM measurements produced lower modal value than Coulter counter measurements.

Bulk chemistry of the LTD and control samples was characterised by X-ray fluorescence analysis (Beckhoff et al., 2006), producing weight percentages of the major elemental composition as oxides, and trace elements as parts per million. Prior to the analysis, samples were crushed and ground in a Fritch planetary ball mill. Pressed powder pellets were prepared from the ground samples and major and trace elements were measured on the pellets. Samples were analysed using a Panalytical MagixPro X-Ray fluorescence spectrometer with an $\mathrm{Rb} 4 \mathrm{~kW}$ X-ray tube. The spectrometer was calibrated and the unknown samples were measured using Panalytical SuperQ analytical software. A wide range of international reference standards were used for calibration (Govindaraju, 1989) and GSP-1 and DR-N standards were analysed at the same time as the collected samples to act as internal check standards (see the Supplement). The nominal detection limit of trace elements measurements was $5 \mathrm{ppm}$.

\subsection{Meteorological and back trajectory data}

Meteorological conditions during the dust transportation event were analysed using NCEP/NCAR reanalyses data obtained from the National Oceanic and Atmospheric Administration (NOAA; http://www.esrl.noaa.gov/psd/data/) and station measurements of air temperature, precipitation, wind speed and visibility (see Fig. 2 for locations). Twenty-seven member ensembles of three-dimensional trajectories were calculated using HYSPLIT model run with the Global Data Assimilation System (GDAS) meteorological input (Draxler and Rolph, 2012; http://ready.arl.noaa.gov/HYSPLIT.php). In HYSPLIT, each member of the trajectory ensemble is calculated by offsetting meteorological data by a fixed grid factor (one meteorological grid point in the horizontal and 0.01 sigma unit in the vertical). HYSPLIT was run in the backward mode for the Garabashi Glacier for 05:00 06:00 UTC, 5 May 2009 and in the forward mode for El Mechili (using SS2 location; Table 1) for 3 May 2009.

\subsection{Spaceborne observations}

Data from the Spinning Enhanced Visible and Infra-Red Imager (SEVIRI) on board the Meteosat Second Generation (MSG) satellite were used to reconstruct the dust plume transportation history. MSG is located in a geostationary orbit at $0^{\circ} \mathrm{W}$ over the equator and provides images with $15 \mathrm{~min}$ temporal resolution. The SEVIRI dust red-green-blue (RGB) images were produced from three thermal infrared channels: $10(12.0 \mu \mathrm{m}), 9(10.8 \mu \mathrm{m})$, and $7(8.7 \mu \mathrm{m})$. The RGB composites were created by displaying the differences between channels 10 and 9 as red, 9 and 7 as green and channel 9 as blue (Schepanski et al., 2007). Spatial resolution of the RGB composite images is $3 \mathrm{~km}$ at nadir increasing to $4-6 \mathrm{~km}$ over the Middle East and the Caucasus where satellite view angle reaches $60^{\circ}$. On these images, dust appears bright pink or magenta and clouds appear as dark red. The dust effect on brightness temperature depends on the underlying surface, time of day, moisture content of the atmosphere, and altitude of dust cloud and composite images may favour elevated layers of dust (Pierangelo et al., 2004; Brindley et al., 
2012). The images were downloaded from the EUMETSAT website (www.eumetsat.int) at $15 \mathrm{~min}$ interval starting with 00:00 UTC, 3 May 2009 and ending 12:00 UTC, 6 May 2009.

Data from the Cloud Aerosol Lidar and Infrared Pathfinder Satellite Observation (CALIPSO) mission (http://www-calipso.larc.nasa.gov) were used to characterise vertical distribution of dust during the event. Attenuated backscatter (reflectivity) profiles at $532 \mathrm{~nm}$ are provided by the Cloud-Aerosol Lidar with Orthogonal Polarization (CALIOP) installed on CALIPSO (Winker et al., 2003) with vertical and horizontal resolutions of $60 \mathrm{~m}$ and $12 \mathrm{~km}$, respectively. The CALIOP-derived reflectivity is used as a proxy to describe the dust layer structure as it depends on aerosol concentration and its optical properties (Bou Karam et al., 2010). Two products from the Moderate Resolution Imaging Spectroradiometer (MODIS), acquired daily at about 12:00 UTC, were used for 3-5 May 2009: (i) surface reflectance images to assess the horizontal distribution of dust (http://ladsweb.nascom.nasa.gov) and (ii) the aerosol optical depth (AOD) at $550 \mathrm{~nm}$ fields with a horizontal resolution of $1^{\circ}$ derived using the Deep Blue algorithm (Hsu et al., 2006) from MODIS-Aqua collection 5.1 (http://disc.sci.gsfc.nasa.gov/giovanni/).

\section{Results and discussion}

\subsection{Meteorological conditions between 3 and 6 May 2009}

Heavy dust storms over North Africa in spring are associated with Saharan depressions developing in the area of strong baroclinicity between the African continent and the relatively cold Mediterranean Sea (Barkan et al., 2005; Knippertz et al., 2009a; Schepanski et al., 2009; Bou Karam et al., 2010). Saharan cyclogenesis is often initiated by the formation of deep north-south oriented troughs in the upper atmosphere and associated cold air advection to North Africa whose effect is enhanced by coastal temperature gradient, which is particularly pronounced in spring (Barkan et al., 2005). Prior to the dust transportation event, an upper-air trough extended from south-western Russia and Ukraine to north-western Libya and Tunisia across the Mediterranean Sea on 3 May (not shown). A region of strong baroclinicity formed across northwestern Egypt and north-eastern Libya on 3 May with surface temperature gradient exceeding $10^{\circ} \mathrm{C}$ over $300 \mathrm{~km}$ at 06:00 UTC ( $8 \mathrm{~h}$ local time) with cold air extending to about $28^{\circ} \mathrm{N}$ (Fig. 1a) and $20^{\circ} \mathrm{C}$ by 12:00 UTC. Surface air temperature at Benghazi decreased from $27^{\circ} \mathrm{C}$ at 12:00 UTC 2 May to $14^{\circ} \mathrm{C}$ at 12:00 UTC, 3 May. A depression formed over western Egypt-eastern Libya with an average 6-hourly central sea level pressure (SLP) of $1006 \mathrm{hPa}$ and a trough extending north over the Mediterranean (Figs. 1a and 2a). The 6-hourly average wind speeds exceeded $10 \mathrm{~m} \mathrm{~s}^{-1}$ in northeastern Libya on 3 May near the surface and $18 \mathrm{~m} \mathrm{~s}^{-1}$ at

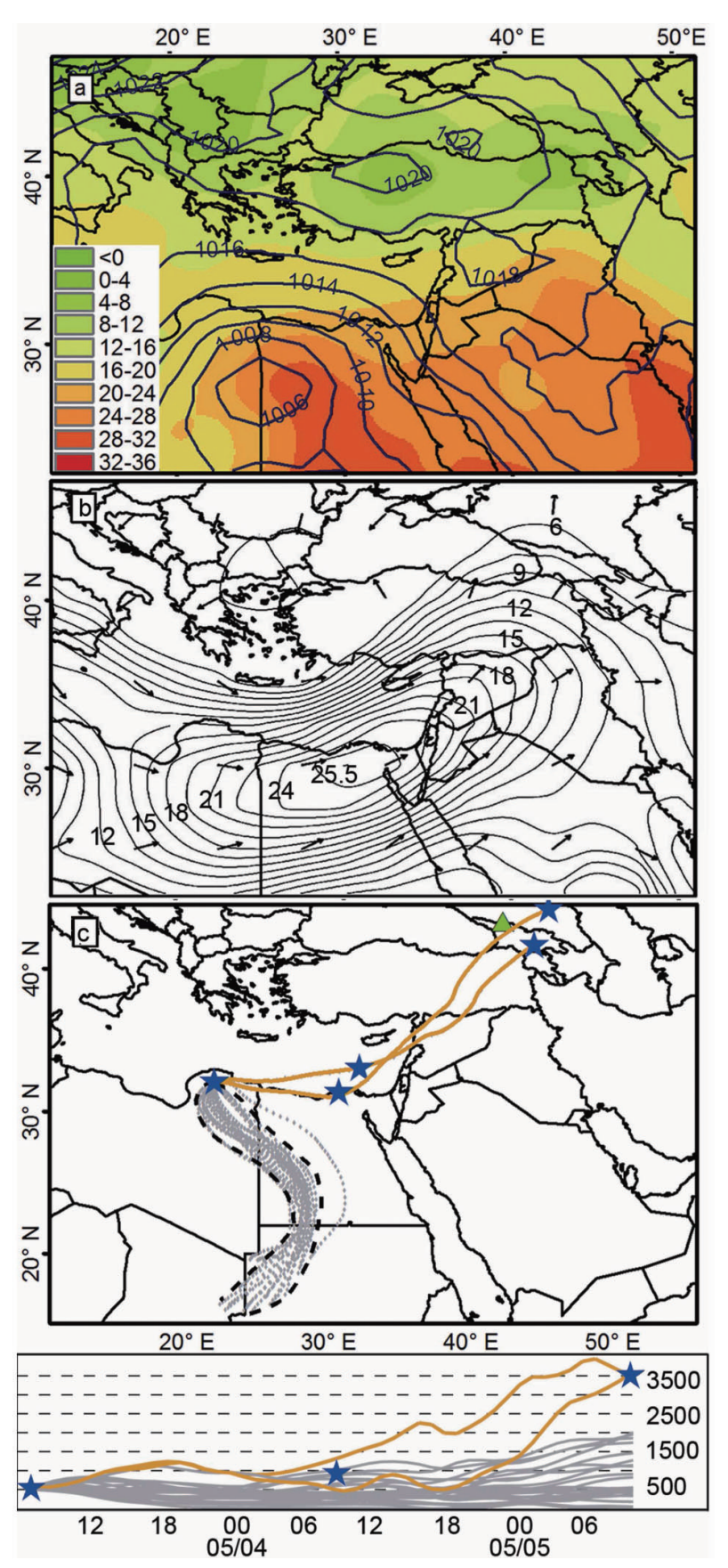

Fig. 1. NCEP/NCAR re-analyses of (a) SLP (hPa) and surface temperature $\left({ }^{\circ} \mathrm{C}\right)$ at 06:00 UTC, 3 May 2009; (b) daily average wind speed $\left(\mathrm{m} \mathrm{s}^{-1}\right)$ and direction at $700 \mathrm{hPa}$ on 4 May 2009; (c) 2-day three-dimensional forward trajectories from HYSPLIT model starting at $32.0144^{\circ} \mathrm{N}, 22.27333^{\circ} \mathrm{E} ; 500 \mathrm{~m}$ above the model earth surface at 10:00 UTC on 3 May 2009. Star signs on (c) mark 24-h intervals; Mt. Elbrus is marked as triangle. Members of trajectory ensemble travelling south are shown in grey; those travelling towards the Caucasus are shown in yellow. 


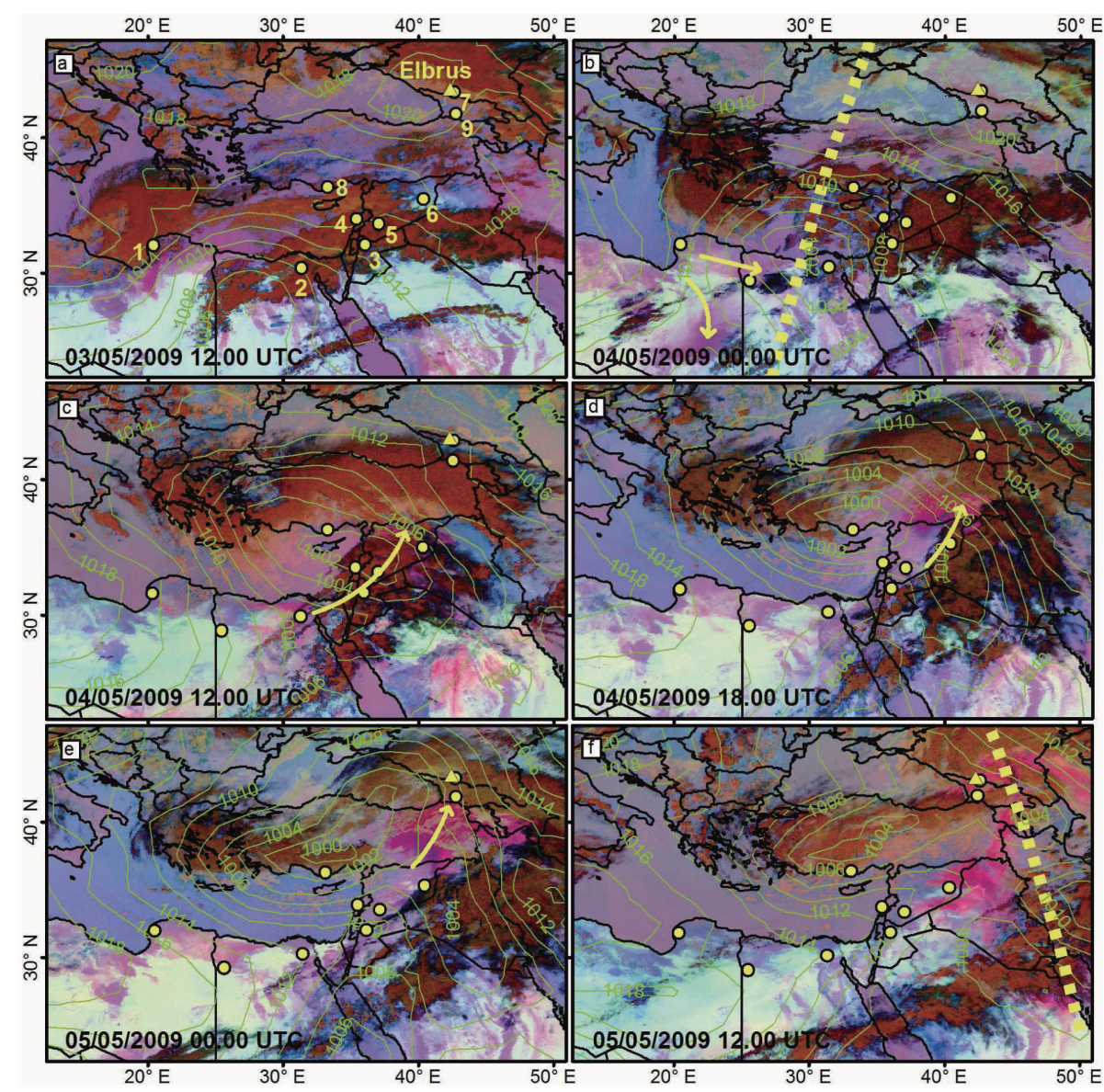

Fig. 2. SEVIRI-derived RGB false color composite images, showing dust (pink/magenta), clouds (brown/orange), and differences in surface emissivity retrieved in absence of dust or clouds (blue). Deserts appear as light green-blue. Isobars are shown as continuous green lines with SLP values (hPa); CALIPSO transects (Fig. 4) as dashed yellow lines and direction of the dust cloud travel as yellow arrows. Meteorological stations: (1) Bengazi, (2) Cairo, (3) Amman, (4) Beirut, (5) Damascus, (6) Deir Ezzor, (7) Terskol, and (8) AERONET sun photometer at Erdemli, (9) lidar location at Abastumani.

$925 \mathrm{hPa}$ (not shown), exceeding the threshold for dust mobilisation (Knippertz et al., 2009a).

On 4 May, strong south-westerly flow from Libya-central Egypt to the Caucasus region established in the middle and upper troposphere with daily mean wind speed exceeding $25 \mathrm{~m} \mathrm{~s}^{-1}$ at $700 \mathrm{hPa}$ (Fig. 1b). The Saharan depression migrated over the eastern Mediterranean towards Turkey with a well-defined trough extending towards Syria and western Iraq (Fig. 2b-d). The highest surface wind speeds were observed in eastern Syria where their 6-hourly averages exceeded $12 \mathrm{~m} \mathrm{~s}^{-1}$. The regional weather stations reported a strong reduction in visibility; a dust storm was reported between 12:00 UTC 3 May to 20:00 UTC 4 May at Cairo and blowing sand was reported on 5 May at Deir Ezzor. On 5 May, the low pressure system was centred over the Black Sea and Turkey with a trough extending towards the Caucasus (Fig. 2e) and strong south-westerly advection from Libya and Egypt to the Caucasus region continued over Syria, Iraq and eastern Turkey, with daily mean wind speeds of about $25 \mathrm{~m} \mathrm{~s}^{-1}$ at the $700 \mathrm{hPa}$ level. While moving over the eastern Mediterranean, the depression produced no rainfall. The first precipitation, associated with the mergence between the Saharan depression and a precipitation-bearing weather front located over the Black Sea (Fig. 2c-f) and subsequent orographic uplift, was registered over Turkey and the southern Caucasus. The low pressure system and associated warm front reached the central Greater Caucasus on 5 May. The daily average air temperature at Terskol station, located $7 \mathrm{~km}$ south-east of Garabashi at $2141 \mathrm{~m}$ a.s.l., increased from $3.0^{\circ} \mathrm{C}$ on 5 May to $6.8^{\circ} \mathrm{C}$ on 6 May and a precipitation total of $13.7 \mathrm{~mm}$ was recorded on 5 May. On 6 May, the low pressure system migrated towards the Caspian Sea, displacing the south-westerly flow towards Iraq and Iran.

\subsection{Evolution of the dust event}

The onset and evolution of the dust event is well documented by the SEVIRI images. Dust mobilisation began between 
09:00 and 10:00 UTC on 3 May following a strong increase in wind speed in the lower troposphere. A dust front positioned along the cold weather front in the Saharan foothills of the Djebel Akhdar in north-eastern Libya is clearly visible on the SEVIRI image at 12:00 UTC (Fig. 2a). The AOD at $550 \mathrm{~nm}$, derived from the MODIS Deep Blue data, increased to 1.5-1.6 in the same location (Fig. 3a). This region has been identified by Schepanski et al. (2009) as an important and persistent source of dust in North Africa with particularly frequent dust activation in spring and early summer in line with the climatology of Saharan depressions (Hannachi et al., 2011). By 00:00 UTC, 4 May, the dust cloud separated into two, with one plume extending along the Mediterranean coast and another migrating south-east from the source region (Fig. 2b). By midday of 4 May, the "northern" dust cloud reached the eastern Mediterranean coast and Syria (Fig. 2c). Preliminary data from a Micro-Pulse Lidar Network (MPLNET) site at Sede Boker $\left(30^{\circ} 51^{\prime} 18^{\prime \prime} \mathrm{N}\right.$; $34^{\circ} 46^{\prime} 55^{\prime \prime}$ ) registered the passage of the dust cloud between 08 and 19:00 UTC on 4 May (not shown). At 12:00 UTC, 4 May (Fig. 2c), the dust layer is concealed under the clouds; however, its trailing band is visible over the Nile delta. MODIS Deep Blue AOD data show values in excess of 2.0 over north-eastern Egypt (Fig. 3b). These data are consistent with the reports on low visibility and blowing sand from regional meteorological stations, particularly Cairo. A CALIOP transect (Fig. 4a) shows the dust band extends between the ground at about $26^{\circ} \mathrm{N}, 28^{\circ} \mathrm{E}$ and $3 \mathrm{~km}$ altitude at $30^{\circ} \mathrm{N}, 29.5^{\circ} \mathrm{E}$. The dust layer appears to be uplifted slantwise along a weather front towards the north-east, with reflectivity values of up to $4 \times 10^{-3} \mathrm{~km}^{-1} \mathrm{sr}^{-1}$. The sun photometer in Erdemli, Turkey (location shown in Fig. 2a) registered a strong increase in AOD on 4 May indicating the passage of the dust cloud (Kokkalis et al., 2012).

On 4 May at 12:00 UTC, a dust layer can be distinguished on the SEVIRI image slightly ahead of the warm front cloud band at the north-eastern flank of the depression, north-east of the Euphrates (Fig. 2c). The brightness temperature of this layer appears different from that of the Saharan dust over the eastern Mediterranean (Fig. 4c) although cloud cover introduced uncertainty in the interpretation of this SEVIRI image. The dust layer located north of the Euphrates becomes more prominent at 18:00 UTC (Fig. 2d). While the difference in brightness temperature may be due to the change in moisture content of the atmosphere (Pierangelo et al., 2004; Brindley et al., 2012), it can also indicate uplift of dust from a different source region in northern Mesopotamia and increasing dust load. Although dust sources in the Middle East were mapped in lesser detail than the Saharan sources, dust sources in north-eastern Syria-northern Iraq were identified by Washington et al. (2003) from the Total Ozone Mapping Spectrometer (TOMS) and more recently with higher resolution by Walker et al. (2009) and Gerivani et al. (2011) from the MODIS surface reflection images and meteorological data, and by Ginoux et al. (2012) from the MODIS

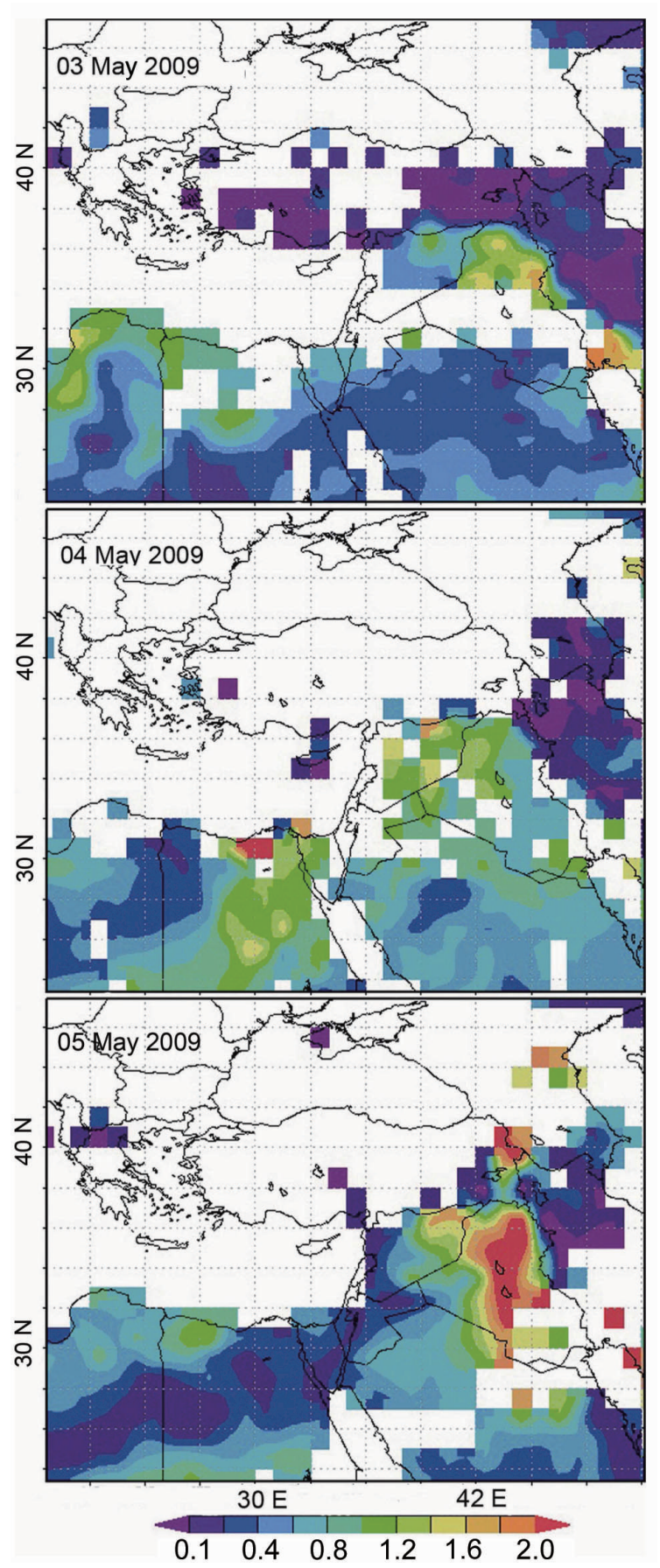

Fig. 3. Aerosol optical depth at $550 \mathrm{~nm}$ retrieved by the MODIS Deep Blue Level 2 algorithm at about 12:00 UTC on (a) 3 May, (b) 4 May, and (c) 5 May.

Deep Blue data. The MODIS Deep Blue data show that AOD over northern Iraq and Syria reached 1.5-1.6 on 3 and 4 May (Fig. 3) and this is one of the areas where Walker et al. (2009) and Ginoux et al. (2012) identified multiple small-scale sources of dust frequently contributing to dust storms. The $700 \mathrm{hPa}$ air trajectories arriving at Garabashi at 


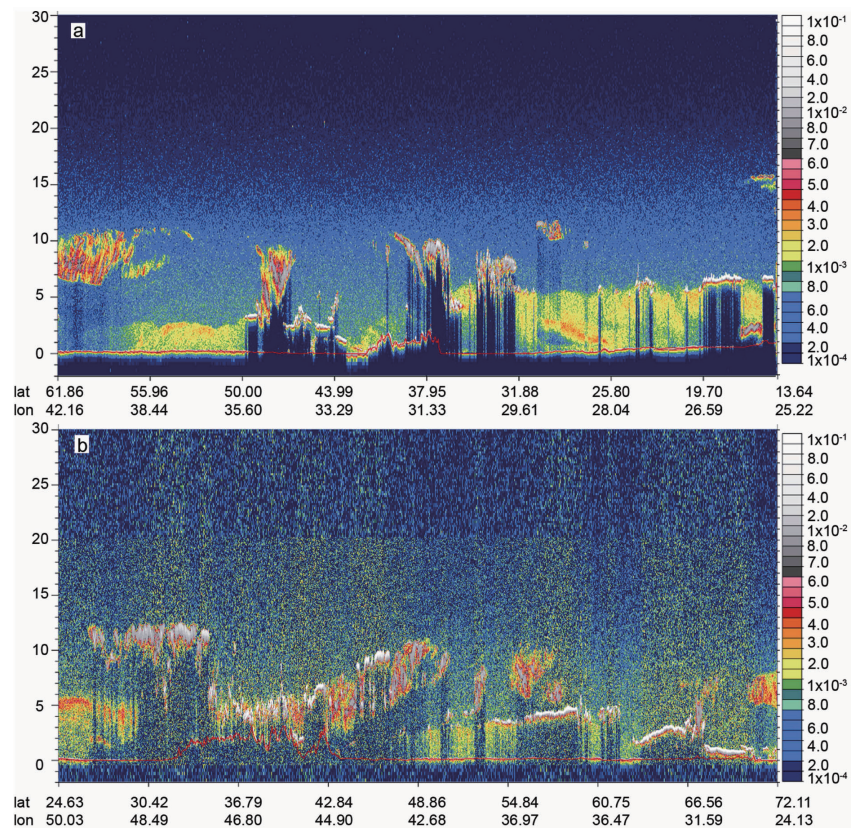

Fig. 4. CALIPSO lidar transects on (a) 00:02-00:16:00 UTC 4 May and (b) 10:14-10:27 5 May showing attenuated backscatter coefficient $\left(\mathrm{km}^{-1} \mathrm{sr}^{-1}\right)$ profiles at $532 \mathrm{~nm}$ with $60 \mathrm{~m}$ vertical and $12 \mathrm{~km}$ horizontal resolution. The outline of the topography is shown as the solid orange line. Thick clouds appear in white and dust clouds in orange-red.

06:00 UTC on 5 May originate from this area (not shown) beginning their progression north on 4 May. On this day, lidar measurements at Abastumani, Georgia at an elevation of 1600 m a.s.l. (Fig. 2a) registered layers of dust at different elevations between $2100 \mathrm{~m}$ a.s.l. and $3400 \mathrm{~m}$ a.s.l. and were attributed by Kokkalis et al. (2012) to the Mesopotamian and Saharan sources, respectively.

On the SEVIRI image from 00:00 UTC, 5 May (Fig. 2e), the warm weather front extending from the eastern Black Sea across the Caucasus Mountains is visible as a deep red band. The dust plume is clearly visible in the warm sector of the depression over Iraq, eastern Turkey and the southern Caucasus, both on the SEVIRI (Fig. 2e) and MODIS surface reflection (Fig. 5) images. The dust cloud reached the Elbrus area between 05:00 and 06:00 UTC (8-9 a.m. local time). A CALIOP transect for 10:15 UTC (position shown in Fig. 2f) shows that the dust extends throughout the middle troposphere, gaining altitude with the orographic uplift across the Greater Caucasus (Fig. 4b). AOD values exceeded 2.0 in central Iraq and over the central Greater Caucasus, although most of the Caucasus was concealed by clouds at the time of MODIS acquisition (Fig. 3c).

The $13.7 \mathrm{~mm}$ of precipitation registered at Terskol on the 5 to early 6 May indicates wet deposition of dust. Significant layers of mineral aerosol are typically formed in snow when a dust-containing air mass mixes with a precipitation-bearing

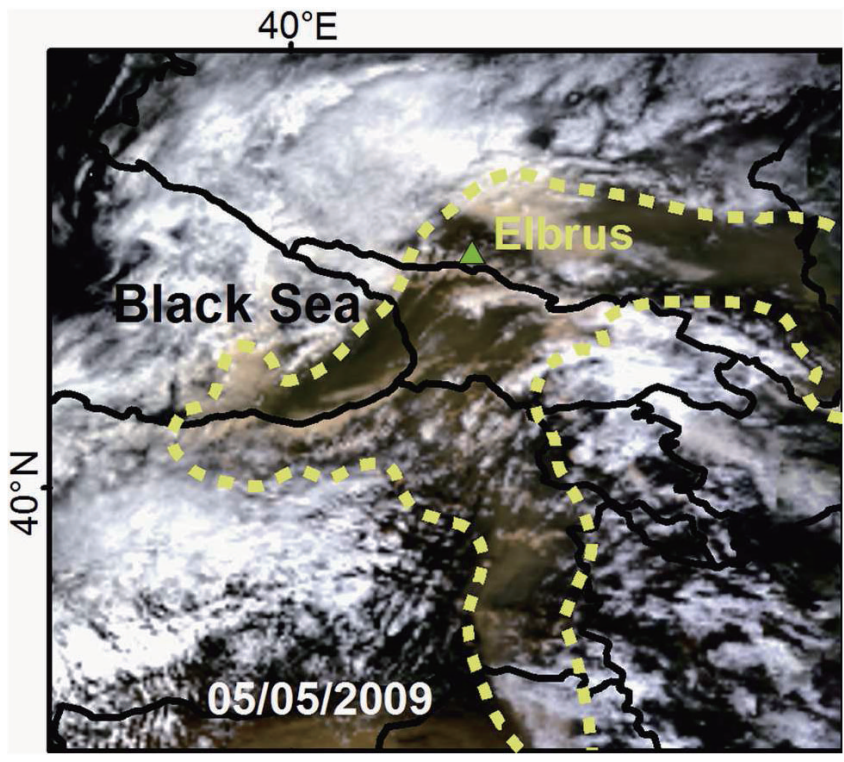

Fig. 5. MODIS surface reflection image showing the dust cloud (brown) over the Caucasus on 5 May 2009.

frontal system (Osada et al., 2004), as on 5 May. A brown layer of dust formed on the slopes of Mt. Elbrus extending to the summit at $5642 \mathrm{~m}$ a.s.l. The weight of the collected sample indicted dustfall of $0.52 \mathrm{~g} \mathrm{~m}^{-2}$ at the sample collection point. In June 2009, a distinct dark dust horizon was uncovered at shallow depth in snow pits at an altitude of $5100 \mathrm{~m}$ a.s.l. where dustfall was calculated as $0.67 \mathrm{~g} \mathrm{~m}^{-2}$.

The forward trajectories starting from $250 \mathrm{~m}$ (not shown) and $500 \mathrm{~m}$ above ground level (Fig. 1c) at SS2 location (Table 1) between 10:00 and 11:00 UTC on 3 May show uplift of dust from the surface to about 1000-1500 m a.s.l. and its transportation along (i) the Mediterranean coast ("northern" cloud in Fig. 2b) and (ii) south from the source region ("southern" cloud in Fig. 2b). The (i) group of trajectories follows the coast at low elevations for about $800 \mathrm{~km}$ ascending east of the Nile data in the region where the reanalyses data exhibits a strong maximum in vertical velocities (not shown). They arrive at the central Greater Caucasus between 05:00 and 07:00 UTC on 5 May at the altitudes of 3700 $3900 \mathrm{~m}$ a.s.l., about $60 \mathrm{~km}$ east of the Garabashi Glacier, i.e. at a distance that is lower than the HYSPLIT horizontal resolution of $1^{\circ}$. HYSPLIT was run in backward mode with an ensemble of back trajectories started from Garabashi at an elevation of $4000 \mathrm{~m}$ a.s.l. at 05:00 UTC, 5 May 2009 (not shown). A group of back trajectories from this ensemble arrive at north-eastern Libya at the time of dust mobilisation on 3 May. The differences between the end-points of back trajectories and the starting point of forward trajectory varied between $200 \mathrm{~km}$ and $300 \mathrm{~km}$ and this was taken as an uncertainty measure in the location of source regions using the trajectory method. Another group of back trajectories from the ensemble arrive at north-eastern Syria on 4 May, descending 


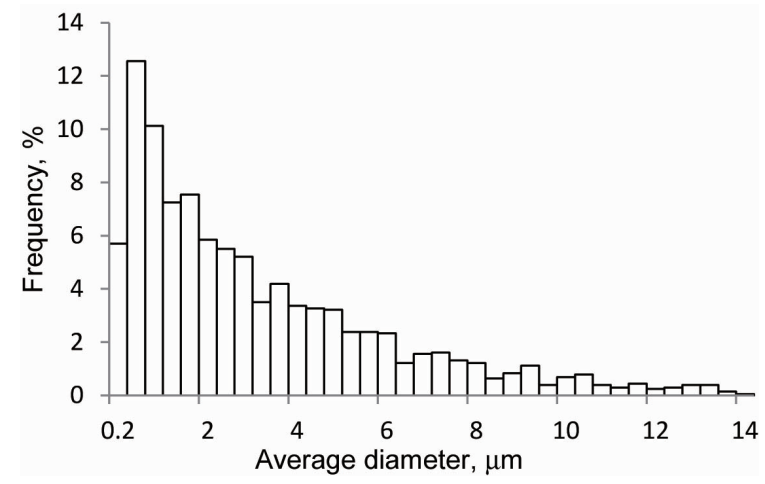

Fig. 6. Number particle size distribution in the LTD sample using $0.4 \mu \mathrm{m}$ bins. The cut-off point for particle diameter measurements is $0.2 \mu \mathrm{m}$; the maximum particle size is $35.42 \mu \mathrm{m}$.

to $200-400 \mathrm{~m}$ a.s.l. over the region where the dust cloud is visible on SEVIRI (Fig. 2c and d).

\subsection{Particle size distribution}

The number size particle distribution is shown in Fig. 6 . The mean and median diameters in the sample were $3.58 \mu \mathrm{m}$ and $2.48 \mu \mathrm{m}$, respectively. The number size distribution is dominated by particles with average diameter below $8 \mu \mathrm{m}$ which account for $90 \%$ of all measured particles in the sample while clay fraction material $(<2 \mu \mathrm{m})$ accounts for $43 \%$. The data are in agreement with the sun photometer measurements at Erdemli, which indicate that particles with diameter of about $2-12 \mu \mathrm{m}$ predominated on 4 May, accounting for about $57 \%$ of the total AOD over southern Turkey (Kokkalis et al., 2012). In our sample, particles with $2-12 \mu \mathrm{m}$ average diameter accounted for $61 \%$ of all measured particles. These results are comparable with Saharan dust size distributions for the Alps, Mediterranean and in the trans-Atlantic regions summarised by Goudie and Middleton (2001).

\subsection{Mineralogical and trace element composition}

The XRF data (see Supplement; Fig. 7) showed that the chemistry of the LTD sample was different from dust liberated from local sources. Most noticeably, LTD was enriched in hematite $\left(\mathrm{Fe}_{2} \mathrm{O}_{3}\right)$ and $\mathrm{MgO}$, which are common in Saharan dust (Guieu et al., 2002; Costillo et al., 2008). Their concentrations in the El Mechili samples, especially SS2, were comparable with the LTD sample from the Garabashi Glacier (Fig. 7). Concentrations of $\mathrm{Fe}_{2} \mathrm{O}_{3}$ and $\mathrm{Al}_{2} \mathrm{O}_{3}$ in the LTD sample are close to those recovered in other locations in Europe, while concentrations of $\mathrm{MgO}$ are higher (Goudie and Middleton, 2001). Concentration of $\mathrm{CaO}$ in the LTD sample is considerably lower than in the Saharan control samples and lower that an average of $8.6 \%$ reported for the Saharan dust transported to Europe (Goudie and Middleton, 2001). Calcium is used as a tracer of Saharan dust (Schwikowski
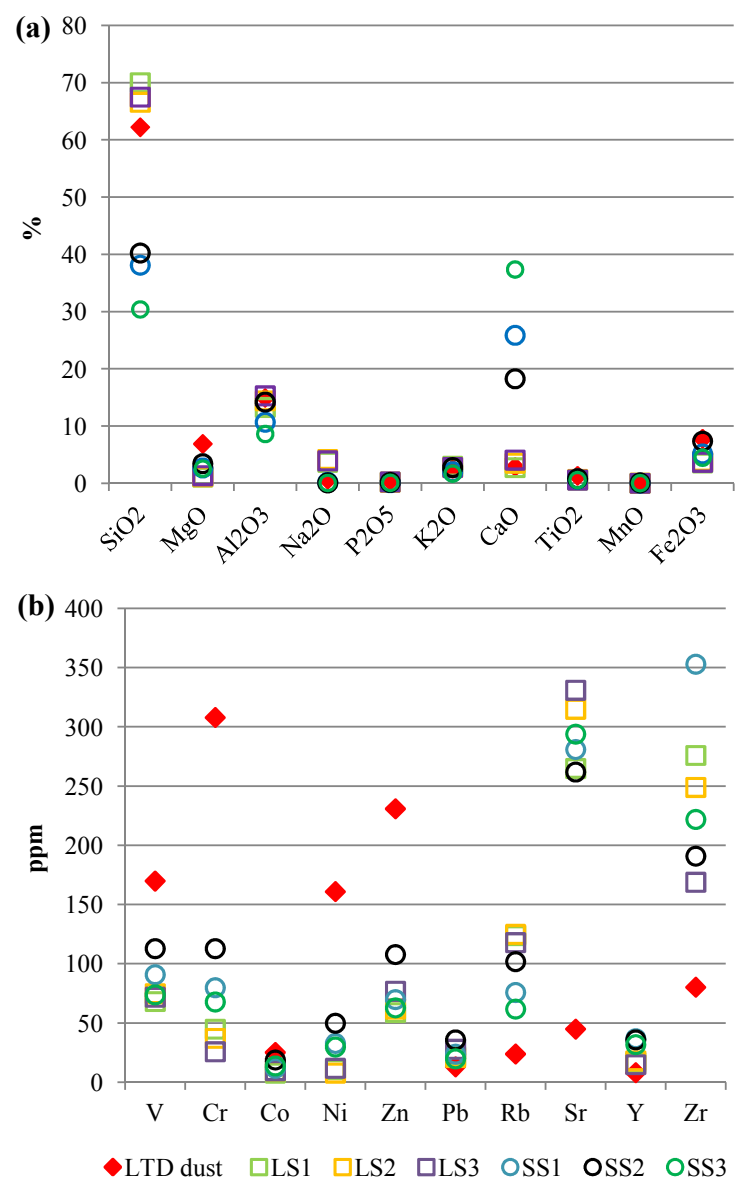

Fig. 7. (a) Chemical analysis of major elements (\%) and (b) trace elements (ppm) in the LTD dust sample from the Garabashi Glacier compared to local sediments (LS) and the Saharan soils from the source region (SS), derived from XRF analysis. Data for copper and analyses of GSP-1 and DRN standards are presented in the Supplement.

et al., 1995); however, removal of calcium is typical of the longer transport paths due to its higher solubility (Sodemann et al., 2006). SEM analysis showed that freshwater Aulacoseira diatoms, found in the Saharan palaeolakes (Moreno et al., 2006), were present in the LTD sample.

Several trace elements are present in greater concentrations in the LTD sample than in the Saharan soil control samples, indicating either enrichment during transportation or contribution of the Mesopotamian sources. We note overabundance of copper accompanied by high concentrations of nickel and zinc, which are frequently contained in the same ores. Concentration of copper reaches $1656 \mathrm{ppm}$ in the LTD sample (see Supplement). In the locally produced dust it varies between $7 \mathrm{ppm}$ and $19 \mathrm{ppm}$ and in the Saharan samples it varies between $19 \mathrm{ppm}$ and $25 \mathrm{ppm}$. Castillo et al. (2008) reported extremely high concentrations of copper comparable with those in the LTD sample in some Saharan soils; nevertheless, comparison with the control samples 
from the Saharan source region indicate that the most probable source is copper-smelting facilities in eastern Turkey and Armenia over which the dust plume travelled. Copper contained in the mineral aerosol is potentially toxic to marine ecosystems (Paytan et al., 2009); however, copper in uncontaminated mineral aerosol has a solubility of $1-7 \%$ and its potential toxicity is lower than that of anthropogenic copper which has solubility of 10-100\% (Sholkovitz et al., 2010). Mineral dust is a known vector for transportation of copper to glaciers and ice sheets (Hong et al., 1996; Marx et al., 2005) and it is important to investigate its origin and whether its over-abundance is typical of LTD deposition in the Caucasus using a larger selection of LTD samples from other deposition events. The LTD sample exhibited high concentrations of vanadium and chromium (Fig. 7b) associated with oiland coal-burning power plants, respectively. While concentrations of lead in the Saharan control samples agreed well with those published in literature (Guieu et al., 2002; Moreno et al., 2006), its low concentration in the LTD sample was unexpected assuming transportation over the densely populated eastern Mediterranean (Fig. 7b). Lead of anthropogenic origin accounts for $20-70 \%$ of its total concentration in Saharan dust samples deposited in Europe (Guieu et al., 2002). Analysis of concentrations of lead in dust transported to Israel showed that dust that from North Africa was strongly enriched in lead, particularly if it passed over Cairo, whereas dust transported from the Arabian peninsula was not (Erel et al., 2006). The low concentrations of lead in the LTD sample at its partial origin in northern Mesopotamia and transportation over regions with low urbanisation or alternatively they can point at the transportation over the Mediterranean Sea as some of the forward trajectories suggest (Fig. 1c).

\section{Conclusions}

The significant dust deposition event of 5 May 2009 on the Garabashi glacier has enabled the development of an approach using multiple independent techniques, allowing high resolution dating and "provenancing" of dust horizons deposited in snow pack and glacier ice, with potential for generic application in other glaciated regions with a sparse network of high-altitude meteorological stations. Dust horizons in the snowpack can be linked to specific dust transport events recorded in remote sensing and meteorological data archives.

The foothills of Djebel Akhdar in eastern Libya were identified as a primary source of dust deposited on the Garabashi Glacier on 5 May 2009 through the analyses of the SEVIRI RGB dust composite imagery with 15-min temporal resolution, together with back- and forward trajectories calculated using the HYSPLIT model. Analysis of both local meteorological and synoptic data in the context of conditions for dust mobilisation and transportation (e.g. Knippertz et al., 2009a; Schepanski et al., 2009) confirmed that the observed cold advection from the Mediterranean, formation of a lowpressure system over the Libyan desert, and sufficiently high wind speeds in the boundary layer favoured activation of the dust sources.

The particle size distribution, dominated by particles with an average diameter under $8 \mu \mathrm{m}$, was in agreement with size of the Saharan dust travelling over $2000 \mathrm{~km}$ (Goudie and Middleton, 2001). Elemental analysis of the LTD and Saharan soil control samples showed a close match in concentrations of hematite in the dust deposited on the Garabashi Glacier and soil collected from a palaeolake in the El Mechili source region. More detailed characterisation of chemical properties of this and other LTD samples is under way using inductively coupled plasma mass spectrometry (ICPMS) analysis.

The novelty and main advantage of the proposed methodology is its ability to identify sources and pathways of dust with high temporal (hours) and spatial (ca. $100 \mathrm{~km}$ ) resolution enabled by the SEVIRI RGB dust product and in verification of results by independent techniques. The high importance of mesoscale processes in activation of dust sources has been recently highlighted (Knippertz et al., 2009b; Schepanski et al., 2009), and the achieved improvement in both temporal and spatial resolution of dust "provenancing" is an advance on previous applications of trajectory and satellite imagery analyses (e.g. Grousset et al., 2003; Osada et al., 2004; Sodemann et al., 2006). As a qualitative data set, the SEVIRI RGB product provides considerably more detailed information on dust plume transportation than frequently used MODIS surface reflection imagery due to much more frequent temporal sampling by SEVIRI (i.e. $15 \mathrm{~min}$ versus daily) and because of the problem of distinguishing aerosol signal from the surface reflectance over the desert areas using MODIS imagery. MODIS AOD fields were used in this study, however, AOD fields, derived from SEVIRI observations, became available as MSG - UK MetOffice product from March 2010 at hourly resolution (Brindley and Russell, 2009). Comparison of these data with AERONET in situ observations, MODIS Deep Blue AOD and Multiangle Imaging Specrtoradiometer (MISR) data were published by Brindley and Russell (2009) and Christopher et al. (2011). The study by Brindley and Russell (2009) indicates that while there is a good agreement between the examined data sets, higher uncertainties in SEVIRI AOD fields may exist over North Africa and Arabia.

The main uncertainty in "provenancing" LTD is the potential contribution of secondary sources of dust located along the track of the Saharan dust mass. In this analysis, the back trajectories and the SEVIRI images pointed to a potential secondary source of dust in northern Mesopotamia, where meteorological conditions were conducive to the entrainment of dust. A lack of detailed characterisation of chemical properties of dust from Syria and Iraq made identification of these potential secondary sources less certain. While the Middle Eastern sources appear to contribute to dust deposition in the 
Caucasus, they do not contribute to dust deposition in the European Alps and the Pyrenees where application of the proposed technique will be more straightforward.

As a result, we propose the following approach for identifying dust deposition events and detailed "provenancing" of long travelled dust recorded in high-altitude glaciers:

1. Analyses of local meteorological data (i.e. occurrence of precipitation) and regional meteorological fields (i.e. air flow at $700-500 \mathrm{hPa}$ ) enable preliminary identification of dates and weather conditions under which dust transportation and deposition are possible. On their own, these data do not provide undisputable evidence that transportation and scavenging of mineral aerosol occurred (Sodemann et al., 2006), but further examination of MODIS AOD fields derived using the Deep Blue algorithm (Hsu et al., 2004) shows whether dust aerosol was present over the study region and indicates possible source regions of aerosol.

2. Calculations of three-dimensional kinematic backtrajectory ensembles with a time step of $1-6 \mathrm{~h}$ provide information on the potential source regions of desert dust and its pathways in the atmosphere. The spatial spread of the ensembles characterises uncertainties of the method due to the uncertainties in meteorological fields and calculation techniques and helps to evaluate the coherence of the air flow and reliability of the potential source regions. Detailed maps of dust sources in the Sahara published by Schepanski et al. $(2007,2009)$ and discussed in the context of seasonal and diurnal conditions of dust storm activation provide additional data for the identification of distant sources of dust deposited on glaciers. Maps of dust sources produced by Walker et al. (2009) and Ginoux et al. (2012) provide additional data for the identification of dust sources in the Middle East.

3. Once the broad source regions of dust and approximate (within a few days) timing of deposition and mobilisation events have been established, analysis of SEVIRI RGB dust composite imagery, in combination with meteorological data and criteria on dust mobilisation, enable high-precision "provenancing" of the longtravelled dust. Forward air trajectories verify dust tracks derived from the SEVIRI imagery, especially in the presence of cloud cover.

As a next step in this research, the proposed approach is being used to provenance LTD deposited on Mt. Elbrus between 2009 and 2012. A longer-term dust deposition climatology will be developed from shallow ice cores obtained at about $5000 \mathrm{~m}$ a.s.l. and compared with the deposition climatology simulated using HiGAM, the atmospheric component of the High-resolution Global Environmental Model (HiGEM, Shaffrey et al., 2009).
Supplementary material related to this article is available online at: http://www.atmos-chem-phys.net/13/ 1797/2013/acp-13-1797-2013-supplement.pdf.

Acknowledgements. This work is a part of the Royal Society International Joint Project "Impacts of Dust Deposition on Glacier Melt in the Caucasus Mountains, Russia" (project N JP100235) and FP7 Marie Curie project DIOGENES (Dust Impacts On Glaciated Environments; contract N 275071).

Edited by: C. Mitsakou

\section{References}

Abed, A. M., Al Kuisi, M., and Khair, H. M.: Characterization of the Khamaseen (spring) dust in Jordan, Atmos. Environ., 43, 2868 2876, 2009.

Barkan, J., Alpert, P., H. Kutiel, and Kishcha P.: Synoptics of dust transportation day from Africa toward Italy and central Europe, J. Geophys. Res., 110, D07208, doi:10.1029/2004JD005222, 2005.

Beckhoff, B., Kanngießer, B., Langhoff, N., Wedell, R., and Wolff, H.: Handbook of Practical X-Ray Fluorescence Analysis, Berlin, Springer Verlag, 2006.

Bou Karam, D., Flamant, C., Cuesta, J., Pelon, J., and Williams, E.: Dust emission and transport associated with a Saharan depression: February 2007 case, J. Geophys. Res.-Atmos., 115, D00H27, doi:10.1029/2009JD012390, 2010.

Brindley, H. E. and Russell, J. E.: An assessment of Saharan dust loading and the corresponding cloud-free longwave direct radiative effect from geostationary satellite observations, J. Geophys. Res., 114, D23201, doi:10.1029/2008JD011635, 2009.

Brindley, H. E., Knippertz, P., Ryder, C., and Ashpole, I.: A critical evaluation of the ability of the Spinning Enhanced Visible and Infrared Imager (SEVIRI) thermal infrared red-green-blue rendering to identify dust events: Theoretical analysis, J. Geophys. Res., 117, D07201, doi:10.1029/2011JD017326, 2012.

Castillo, S., Moreno, T., Querol, X., Alastuey, A., Cuevas, E., Herrmann, L., Mounkaila, M., and Gibbons W.: Trace element variation in size-fractionated African desert dusts, J. Arid Environ., 72, 1034-1045, 2008.

Christopher, S. A., Gupta, P., Johnson, B., Ansell, C., Brindley, H., and Haywood, J.: Multi-sensor satellite remote sensing of dust aerosols over North Africa during GERBILS, Q. J. R. Meteorol. Soc., 137, 1168-1178, 2011.

Dong, Zh., Li, Zh., Xiao, C., Wang, F., and Zhang, M.: Characteristics of aerosol dust in fresh snow in the Asian dust and non-dust periods at Urumqi glacier no. 1 of eastern Tian Shan, China, Environ. Earth Sci., 60, 1361-1368, doi:10.1007/s12665-009-02716, 2009

Draxler, R. R. and Rolph G. D.: HYSPLIT (HYbrid Single-Particle Lagrangian Integrated Trajectory), Model available at: http:// ready.arl.noaa.gov/HYSPLIT.php (last access: 30 May 2012), NOAA Air Resources Laboratory, Silver Spring, MD, 2012.

Erel, Y., Dayan, U., Rabi, R., Rudich, Y., and Stein, M.: Transboundary transport of pollutants by atmospheric mineral dust, Environ. Sci. Technol., 40, 2996-3005, 2006. 
Fujita, K.: Effect of dust event timing on glacier runoff sensitivity analysis for a Tibetan glacier, Hydrol. Process., 21, 2892-2896, 2007.

Gerivani, H., Lashkaripour, G. R., Ghafoori, M., and Jalali, N.: The source of dust storm in Iran: A case study based on geological information and rainfall data, Carpathian, J. Earth Environ. Sci., 6, 297-308, 2011.

Ginoux, P., Prospero, J. M., Gill, T. E, Hsu, N. C., and Zhao, M.: Global-scale attribution of anthropogenic and natural dust sources and their emission rates based on MODIS Deep Blue aerosol products, Rev. Geophys., 50, 1-36, 2012.

Govindaraju, K. (Ed.): Compilation of working values and sample description for 272 geostandards, Geostandards Newsletter, Special Isue, vol. XIII, 113 pp., 1989.

Goudie, A. S. and Middleton, N. J.: Saharan Dust Storms: Nature and consequences, Earth-Sci. Rev., 56, 179-204, 2001.

Grousset, F. E., Ginoux, P., Bory, A., and Biscaye, P. E.: Case study of a Chinese dust plume reaching the French Alps, Geophys, Res. Lett., 30, 1277, doi:10.1029/2002GL016833, 2003.

Guieu, C., Loÿe-Pilot, M.-D., Ridame, C., and Thomas, C.: Chemical characterization of the Saharan dust end-member: some biogeochemical implications for the western Mediterranean Sea, J. Geophys. Res., 107, D15, ACH 5-1-ACH 5-11, doi:10.1029/2001JD000582, 2002.

Hannachi, A., Awad, A., and Ammar K.: Climatology and classification of spring Saharan cyclone tracks, Clim. Dynam., 37, 473491, 2011

Hong, S., Candelone, J. P., Patterson, C. C., and Boutron, C. F.: History of ancient copper smelting polltuion during Roman and medieval times recorded in Greenland ice, Science, 272, 246249, 1996

Hsu, N. C., Tsay, S. C., King, M. D., and Herman, J. R.: Deep Blue Retrievals of Asian Aerosol Properties During ACE-Asia, IEEE Trans. Geosci. Remote Sens., 44, 3180-3195, 2006.

Kandler, K., Lieke, K., Benker, N., Emmel, C., Upper, M. K., UllerEbert, D. M., Ebert, M., Scheuvens, D., Schladitz, A., Schutz, L., and Weinbruch, S.: Electron microscopy of particles collected at Praia, Cape Verde, during the Saharan Mineral Dust Experiment: Particle chemistry, shape, mixing state and complex refractive index, Tellus, 63B, 475-496, 2011.

Kang, S., Zhang, Y., Zhang, Y., Grigholm, B., Kaspari, S., Qin, D., Ren, J., and Mayewski, P. A.: Variability of atmospheric dust loading over the central Tibetan Plateau based on ice core glaciochemistry, Atmos. Environ., 44, 2980-2989, 2010.

Knippertz, P., Ansmann, A., Althausen, D., Mueller, D., Tesche, M., Bierwirth, E., Dinter, T., Mueller, T., Von Hoyningen-Huene, W., Schepanski, K., Wendisch, M., Heinold, B., Kandler, K., Petzold, A., Schuetz, L., and Tegen, I.: Dust mobilization and transport in the northern Sahara during SAMUM 2006 - a meteorological overview, Tellus B, 61, 12-31, doi:10.1111/j.16000889.2008.00380.x, 2009a.

Knippertz, P., Trentmann, J., and Seifert, A.: High-resolution simulations of convective cold pools over the northwestern Sahara, J. Geophys. Res-Atmos., 114, D8, doi:10.1029/2008JD011271, 2009b.

Kokkalis, P., Mamouri, R. E., Todua, M., Didebulidze, G. G., Papayannis, A., Miridis, V., Basart, S., Pérez, C., and Baldasano, J. M.: Ground-, satellite- and simulation-based analysis of a strong dust event over Abastumani, Georgia, during May 2009, Int. J.
Remote. Sens., 16, 4886-4901, 2012.

Li, Z., Zhao, S., Edwards, R., Wang, W. and Zhou, P.: Characteristics of individual aerosol particles over Ürümqi Glacier No. 1 in eastern Tianshan, central Asia, China. Atmos. Res., 99, 57-66, 2011.

Marx, S. K., Kamber, B. S., and McGowan, H. A.: Provenance of long-travelled dust determined with ultra-trace-element composition: A pilot study with samples from New Zealand glaciers, Earth Surf. Proc. Land., 30, 699-716, 2005.

McGowan, H. A., Kamber, B., McTainsh, G. H., and Marx, S. K.: High resolution provenancing of long travelled dust deposited on the Southern Alps, New Zealand, Geomorphology, 69, 208-221, 2005.

Moreno, T., Querol, X., Castillo, S., Alastuey, A., Cuevas, E., Herrmann, L., Mounkaila, M., Elvira, J., and Gibbons, W.: Geochemical variations in aeolian mineral particles from the SaharaSahel Dust Corridor, Chemosphere, 65, 261-70, 2006.

Oerlemans, J., Giesen, R. H., and Van Den Broeke, M. R.: Retreating alpine glaciers: increased melt rates due to accumulation of dust (Vadret da Morteratsch, Switzerland), J. Glaciol., 55, 729_ 736, 2009.

Osada, K., Iida, H., Kido, M., Matsunaga, K., and Iwasaka, Y.: Mineral dust layers in snow at Mount Tateyama, Central Japan: formation processes and characteristics, Tellus, 56, 382-392, 2004.

Paytan, A., Mackey, K., Chen, Y., Lima, I., Doney, S., Mahowald, N., Labiosa R., and Post A.: Toxicity of atmospheric aerosols on marine phytoplankton, Proc. Natl. Aca. Sci., 106, 4601-4605, 2009.

Pierangelo, C., Chédin, A., Heilliette, S., Jacquinet-Husson, N., and Armante, R.: Dust altitude and infrared optical depth from AIRS, Atmos. Chem. Phys., 4, 1813-1822, doi:10.5194/acp-41813-2004, 2004.

Prasad, A. K., Yang, K.-H. S., El-Askary, H. M., and Kafatos, M.: Melting of major Glaciers in the western Himalayas: evidence of climatic changes from long term MSU derived tropospheric temperature trend (1979-2008), Ann. Geophys., 27, 4505-4519, doi:10.5194/angeo-27-4505-2009, 2009.

Reid, E. A., Reid, J. S., Meier, M. M., Dunlap, M. R., Cliff, S. S., Broumas, A., Perry, K., and Maring, H.: Characterization of African dust transported to Puerto Rico by individual particle and size segregated bulk analysis, J. Geophys. Res., 108, 8591, doi:10.1029/2002JD002935, 2003a.

Reid, J. S., Jonsson, H. H., Maring, H. B., Smirnov, A., Savoie, D. L., Cliff, S. S., Reid, E. A., Livingston, J. M., Meier, M. M., Dubovik, O., and Tsay, S.-C.: Comparison of size and morphological measurements of coarse mode dust particles from Africa, J. Geophys. Res., 108, 8593, doi:10.1029/2002JD002485, 2003 b.

Rototaeva, O. V., Khmelevskoy, I. F., Bazhev, A. B., Hetzimberg, J., Stenberg, M., and Pinglot, J. F.: Structure and chemical composition of the Bolshoy Azau glacier active layer, Data Glaciol. Studies, 84, 25-33, 1998 (in Russian).

Rototaeva, O. V., Kerimov, A. M., and Khmelevskoy, I. F.: Macrochemical composition of Elbrus southern slope glaciers, Data Glaciol. Studies, 87, 98-105, 1999 (in Russian).

Royer, A., De Angelis, M., and Petit, J. R.: A 30000 year record of physical and optical properties of microparticles from an East Antarctic ice core and implications for paleoclimate reconstruction models, Climate Change, 5, 381-412, 1983. 
Schepanski, K., Tegen, I., Laurent, B., Heinold, B., and Macke, A.: A new Saharan dust source activation frequency map derived from MSG-SEVIRI IR channels, Geophys. Res. Lett., 34, L18803, doi:10.1029/2007GL030168, 2007.

Schepanski, K., Tegen, I., Todd, M. C., Heinold, B., Bönisch, G., Laurent, B., and Macke, A.: Meteorological processes forcing Saharan dust emission inferred from MSG-SEVIRI observations of subdaily dust source activation and numerical models, J. Geophys. Res., 114, D10201, doi:10.1029/2008JD010325, 2009.

Schwikowski, M., Seibert, P., Baltensperger, U., and Gaggeler, H. W.: A study of an outstanding Saharan dust event at the high-alpine site Jungfraujoch, Switzerland, Atmos. Environ., 29, 1829-1842, 1995.

Shaffrey, L. C., Stevens, I., Norton, W. A., Roberts, M. J., Vidale, P. L., Harle, J. D., Jrrar, A., Stevens, D. P., Woodage, M. J., Demory, M. E., Donners, J., Clark, D. B., Clayton, A., Cole, J. W., Wilson, S. S., Connolley, W. M., Davies, T. M., Iwi, A. M., Johns, T. C., King, J. C., New, A. L., Slingo, J. M., Slingo, A., SteenmanClark, L., and Martin, G. M.: UK HiGEM: The New UK HighResolution Global Environment Model-Model Description and Basic Evaluation, J. Climate., 22, 1861-1896, 2009.

Sheehy, D. P.: A perspective on desertification of grazing land ecosystems in North China, Ambio, 21, 303-307, 1992.

Sholkovitz, E. R., Sedwick, P. N., and Church, T. M.: On the fractional solubility of copper in marine aerosols: Toxicity of Aeolian copper revisited, Geophys. Res. Lett., 37, L20601, doi:10.1029/2010GL044817, 2010.
Sodemann, H., Palmer, A. S., Schwierz, C., Schwikowski, M., and Wernli, H.: The transport history of two Saharan dust events archived in an Alpine ice core, Atmos. Chem. Phys., 6, 667-688, doi:10.5194/acp-6-667-2006, 2006.

Sokolik, I. N. and Toon, O. B.,: Direct radiative forcing by anthropogenic airborne mineral aerosols, Nature, 381, 681-683, 1996.

Stokes, C. R., Gurney, S. D., Shahgedanova, M., and Popovnin, V.: Late-20th-century changes in glacier extent in the Caucasus Mountains, Russia/Georgia, J. Glaciol., 52, 99-109, 2006.

Takeuchi, N. and Li, Z.: Characteristics of Surface Dust on Urumqi Glacier No. 1 in the Tien Shan, Arct. Antarct. Alp. Res., 40, 744750, 2008.

Walker, A. L., Liu, M., Miller, S. D., Richardson, K. A., and Westphal, D. L.: Development of a Dust Source Database for Mesoscale Forecasting in Southwest Asia, J. Geophys. Res., 114, D18207, doi:1029/2008JD011541, 2009.

Washington, R., Todd, M., Middleton, N. J., and Goudie, A. S.: Dust-Storm Source Areas Determined by the Total Ozone Monitoring Spectrometer and Surface Observations, Ann. Assoc. Amer. Geog., 93, 297-313, 2003.

Winker, D. M., Pelon, J., and McCormick, M. P.: The CALIPSO mission: Spaceborne lidar for observation of aerosols and clouds, Proc. SPIE, 4893, 1-11, 2003. 